\title{
Зачем историку авантюрист?
}

\section{Why Should Historians Study Adventurers?}

\author{
Яна Ларина \\ НИИ военной истории Военной академии Генштаба \\ Iana Larina \\ Research and Development Institute of Military History of the Military Academy of \\ the General Staff of the Armed Forces of the Russian Federation \\ jana.larina@gmail.com
}

Рецензия на книгу: Франиузский авантюрист при дворе Петра I: Письма и бумаги барона де Сент-Илера / авт. науч. сост. и науч. ред. И. И. Федюкин. Москва: Изд. дом Высшей школы экономики, 2018. $351 \mathrm{c.}$

Review of A French Adventurer at the Court of Peter I: The Letters and Papers of Baron de SaintHillaire. Edited by I. I. Fediukin. Moscow: Izd. Dom Vysshei shkoly ekonomiki, 2018, 351 p.

Новая книга Игоря Федюкина рассказывает о Жозефе де Сент-Илере - первом директоре Морской академии, основанной в 1715 году в Санкт-Петербурге, объездившем пол-Европы со своими проектами в поисках карьерных перспектив. Книга состоит из двух почти равнозначных по объему разделов. В первом из них кропотливо воссоздана “документальная хроника похождений” (с. 17) Сент-Илера в России и Европе. Во втором разделе под общим названием "Письма и бумаги барона де Сент-Илера” опубликованы 68 документов - письма, проекты и другие тексты самого Сент-Илера и его современников (в том числе графа А. А. Матвеева и кабинетсекретаря Петра I A.В. Макарова). Источники были выявлены И. Федюкиным в архивах Москвы, Санкт-Петербурга, Парижа, Лондона, Вены и Стокгольма. Они включают документы на русском и четырех иностранных языках, над их расшифровкой и переводом трудилась группа специалистов: перевод с французского выполнил Д. А. Кондаков, с немецкого - О. А. Кирикова, с испанского - К. Гуа, с английского - И. И. Федюкин. Иноязычные тексты представлены и на языке оригинала и в русском переводе. 6 документов (№ 21-25, №36) из 68 были ранее опубликованы И. Федюкиным и рассмотрены в контексте истории создания Морской академии. ${ }^{1}$ Однако их повторная публикация в рамках данной работы представляется обоснованной и необходимой.

Что могут дать исследователям похождения и бумаги человека, которого сам автор называет “третьестепенным персонажем”? (С. 23) Л. П. Репина и другие специалисты уже обращали внимание на большой потенциал биографического жанра, причем не в его классическом исполнении “жизни великих и знаменитых,” а в рамках метода персональной истории и концепта человека “второго плана.” В соответствии с этим

${ }^{1}$ См.: И. И Федюкин и М. Б. Ларинович, ред., “Регулярная академия учреждена будет...”: Образовательные проекты в России в первой половине XVIII века (Москва: Новое издательство, 2015), 47-6o. (Sm.: I. I Fediukin and M. B. Larinovich, red., "Regulianaia akademiia uchrezhdena budet...": Obrazovatel'nye proekty $v$ Rossii v pervoi polovine XVIII veka (Moscow: Novoe izdatel'stvo, 2015)). 
подходом, биография рассматривается в историческом контексте, одновременно и как главная цель исследования, и как одно из эффективных средств познания того исторического социума, в котором жил человек. ${ }^{2}$ В фокусе исследования оказывается не выдающаяся историческая личность, а человек более “типичный,” но все же обладающий многочисленными индивидуальными чертами и собственным образом. Он индивидуален, но в сравнении с фигурами “первой величины,” более встроен в социальный контекст, поэтому его биография позволяет исследовать внутренние мотивы поведения и внешние факторы, сущность эпохи в человеческом и социальном измерении. ${ }^{3}$ И. Федюкин прослеживает и собственно биографию СентИлера, и его деятельность в кругу других европейских “коллег,” искателей фортуны и составителей различных реформационных и дипломатических проектов. Благодаря такой двойной оптике рассмотрены следующие важные вопросы.

И. Федюкин исследует феномен прожектерства как особого вида деятельности, условия его существования и показывает, что в начале XVIII века статус "эксперта" только формировался, еще не произошла кодификация и стандартизация прикладных навыков: “Похождения Сент-Илера наглядно иллюстрируют и те особенности формирующегося государства раннего Нового времени, которые сделали возможным появление и функционирование таких прожектеров. Государственный аппарат носит в ту пору весьма рудиментарный характер, поэтому государи и их министры не могут не обращаться к подобным предпринимателям, когда им нужна информация, когда необходимо разработать какие-то планы реформ или сформулировать новые инициативы, когда требуется найти человека для выполнения важного задания" (с. 19). Постановка и разработка вопроса - где же проходила грань между мошенником с его фантастическими проектами и инициативным знатоком в области права - важны для понимания устройства государства раннего Нового времени.

В историографии и исторической публицистике долго бытовало представление об участии “сомнительных” иностранцев в реформационных проектах государственного уровня как специфически российском явлении времен Петра I. Весьма характерно оно было выражено М. М. Богословским, который обрисовал толпу назойливых иностранных прожектеров, “жужжавших” вокруг Петра I. ${ }^{4}$ Близко к этому

2 Л. П. Репина, “Личность и общество, или история в биографиях,” в История через личность. Историческая биография сегодня, ред. Л. П. Репина (Москва: “Кругъ,” 2005), 9. (L. P. Repina, "Lichnost' i obshchesvo, ili istoriia v biografiiakh,” v Istoriia cherez lichnost'. Istoricheskaia biografiia segodnia, red. L. P. Repnina (Moscow: "Krug," 2005), 9).

${ }^{3}$ А. Е. Иванеско, “Биографика, ‘второй план' и парадоксы,” в Слава и забвение. Парадоксы биографики, ред. Л. П. Репина (Санкт-Петербург: Алетейя, 2014), 5-12. (А. E. Ivanesko, “Biografika, 'vtoroi plan' i paradoksy,” v Slava i zabvenie. Paradoksy, biografiki, red. L. P. Repnina (St. Petersburg: Aleteiia, 2014), 5-12). Большие исследовательские перспективы в рамках биографического метода открывает недавно вышедшее издание: В. С. Ржеуцкий и Д. Ю. Гузевич, ред., Иностранные специалисты в России в эпоху Петра Великого: Биографический словарь выходцев из Франции, Валлонии, франкоязычных Швейцарии и Савойи, 1682-1727 (Москва: Ломоносов, 2018). (V. S. Rjéoutski i D. Iu. Guzevich, red., Inostrannye spetsialisty $v$ Rossii $v$ epokhu Petra Velikago: Biograficheskii slovar'vykhodtsev iz Frantsii, Vallonii, frankoiazychnykh Shveitsarii i Savoii, 1682-1727 (Moscow: Lomonosov, 2018)).

4 М. М. Богословский, Областная реформа Петра Великого. Провинция 1719-1727 (Москва: Университетская типография, 1902), 36. (М. M. Bogoslovskii, Oblastnaia reforma Petra Velikogo. Provintsiia 1719-1727 (Moscow: Universitetskaia tipografiia, 1902), 36). М. М. Богословский, “Значение реформы Петра Великого в истории русского дворянства,” в Российский XVIII век: Избранные труды, Т. 1 (Москва: Интелвак, 2008), 32. (M. M. Bogoslovskii, "Znachenie reform Petra Velikogo v istorii russkogo dvorianstva," v Rossiiskii XVIII vek: Izbrannye trudy, T. 1 (Moscow: Intelvak, 2008), 32 ). 
представлению примыкает и общее восприятие роли иностранцев в политической жизни России XVIII века и так называемого “немецкого засилья,” когда, по словам В.О. Ключевского, “немцы посыпались в Россию точно сор из дырявого мешка, облепили двор, обсели престол, забирались на все доходные места в управлении." Современные исследователи уже отмечали непродуктивность подхода, рассматривающего вопрос о роли и деятельности иностранцев России в полемическом ключе. ${ }^{6}$ Наблюдения И. Федюкина вносят дальнейший вклад в преодоление архаичных и упрощенных историографических конструктов и переводят исследование в принципиально иную плоскость: “... важно, что известные нам похождения француза не ограничиваются Россией. Легко было бы себе представить, что иностранный мошенник воспользовался наивным увлечением Петра I и его соратников всем “западным,” чтобы выдать себя за того, кем он не являлся [...] и присвоить себе комически высокий статус в далекой “дикой стране.” Граница между Россией и Европой в этом случае оказалась бы и границей между пространством “цивилизации," где знают цену настоящему знанию и умеют отличить эксперта от самозванца, и краем легковерных “дикарей,” где этой разницы пока еще не понимают и где можно “обнулить” свое прошлое и придумать себе новую биографию. [...] До того как предстать при дворе Петра, он общался с британскими министрами и императорскими наместниками, а дворянство и баронский титул он присвоил себе не при пересечении российской границы, а где-то на полпути между Гаагой и Веной; потерпев же неудачу в России, он, как ни в чем ни бывало, отправился предлагать себя в качестве эксперта при шведском дворе. [...] Если взглянуть на историю его похождений с этой стороны, то петровская Россия не выглядит уникально благоприятным для самозванчества заповедником простаков. Наоборот, оказывается, что она удивительно тесно интегрирована в общеевропейское пространство” (С. 16-17). Правда, в этом контексте заявленная в названии книги локализация “авантюрист при дворе Петра I" не вполне соответствует содержанию, поскольку И. Федюкин подробно рассматривает похождения своего героя в Лондоне, Париже, Вене и других европейских городах.

Обращение к биографии Сент-Илера позволяет автору рассмотреть и другую важную деталь механизма государства Нового времени. Его полушпионская деятельность была связана с составлением многочисленных комбинаций сепаратных договоров воюющих стран и династических матримониальных проектов. Он был вплетен в общеевропейскую систему социальных отношений, которая при отсутствии четкого статуса “эксперта” допускала близость и к европейским монархам, дипломатам, министрам, придворным (среди опубликованных документов есть письма Сент-Илера Петру I, шведскому королю Фредрику I, князю Б. И. Куракину), и к людям далеким от властных кабинетов. И. Федюкин выявил круг лиц, прямо или косвенно связанных с деятельностью Сент-Илера, что позволило ему проследить и проанализировать патрон-клиентские связи, информационные каналы и неформальные дипломатические сети “за фасадом государевой службы” (С. 138). При этом стоит особо отметить, что автор привлек не только опубликованные им в

${ }^{5}$ В. О. Ключевский, Сочинения в девяти томах, Т. 4 (Москва: Мысль, 1989), 272. (V. O. Kliuchevskii, Sochineniia $v$ deviate tomakh, T. 4 (Moscow: Mysl', 1989), 272).

${ }^{6}$ См., например, Е. В. Анисимов, Государственные преобразования и самодержавие Петра Великого (Санкт-Петербург: Дмитрий Буланин, 1997), 102. (Sm. naprimer, E. V. Anisimov, Gosudarstvennye preobrazovaniia i samoderzhavie Petra Velikogo (St. Petersburg: Dmitrii Bulanin, 1997), 102). И. В. Курукин, Анна Иоанновна (Москва: Молодая гвардия, 2014), 11-15. (I. V. Kurukin, Anna Ioannovna (Moscow: Molodaiia gvardiia, 2014), 11-15). 
книге документы, но и обширную переписку европейских посланников и политиков, газеты и другие источники. В книге подробно показана тонкая источниковедческая машинерия и учтены многочисленные подробности дипломатических интриг. Обилие подобных деталей несколько затрудняет восприятие текста, но, несомненно свидетельствует о большой проделанной работе.

Изучение феномена прожектерства, патрон-клиентских связей и политической антропологии государства раннего Нового времени в общеевропейском контексте, в свою очередь, отражает переход от традиционной “контейнерной” парадигмы XIX века, когда основополагающей единицей исследования мыслилось национальное государство, к методологии глобальной истории в ее понимании как "истории связей,” перемещения людей и идей. ${ }^{7}$ Себастьян Конрад обращает внимание на продуктивность исследований, в которых анализируется какой-то один объект со всеми его отличительными свойствами, только помещенный в глобальный контекст. ${ }^{8}$ Книга И. Федюкина как раз отлично иллюстрирует, как работает это сочетание глобального и локального, как могут соотноситься микро- и макроисторический подходы.

“Французский авантюрист при дворе Петра I” открывает серию “Новые источники по истории России. Rossica Inedita," и хочется надеяться, что и последующие книги этой серии будут соответствовать заданному исследовательскому стандарту.

7 Себастьян Конрад, Что такое глобальная история? Пер. с англ. А. Степанова (Москва: Новое литературное обозрение, 2018), 19-20, 26. (Sebast'ian Konrad, Chto takoe global'naia istoriia? Per. s angl. A. Stepanova (Moscow: Novoe literaturnoe obozrenie, 2018), 19-20, 26).

8 Там же, 168-169. (Tam zhe, 168-169). 